\title{
A historical study of utility gardens within the Klemensów palace and park complex
}

\author{
Emilia Chęć \\ emiliachec@gmail.com | (1D) https://orcid.org/0000-0002-3261-4782 \\ Joanna Dudek-Klimiuk \\ joanna_dudek_klimiuk@sggw.edu.pl | (D) https://orcid.org/0000-0003-2131-6082 \\ Institute of Environmental Engineering, Department of Landscape Architecture, \\ Warsaw University of Life Sciences
}

\section{Piotr Szkotut}

pszkolut@kul.pl | (1) https://orcid.org/0000-0000-0002-8873-1187

Institute of Mathematics, Computer Science and Landscape Architecture, Faculty of Science and Health Sciences, John Paul II Catholic University of Lublin

Scientific Editor: Mateusz Gyurkovich, Cracow University of Technology Technical Editor: Aleksandra Urzędowska, Cracow University of Technology Press Language Verification: Skrivanek Translation Office Typesetting: Anna Basista, Cracow University of Technology Press

Received: November 20, 2019

Accepted: July 1, 2021

Copyright: @ 2021 Chęć, Dudek-Klimiuk, Szkotut. This is an open access article distributed under the terms of the Creative Commons Attribution License, which permits unrestricted use, distribution, and reproduction in any medium, provided the original author and source are credited.

Data Availability Statement: All relevant data are within the paper and its Supporting Information files.

Competing interests: The authors have declared that no competing interests exist.

Citation: Chęć, E., Dudek-Klimiuk, J., Szkotut, P. (2021). A historical study of utility gardens within the Klemensów Palace and park complex. Technical Transactions: e2021010. https://doi.org/10.37705/

\begin{abstract}
The main purpose of the research was the historical study of utility gardens, which are separate functional and spatial sections of the palace and park complex in Klemensów. These include a walled-off garden constituting a unique man-made landscape acting as a fruit and vegetable garden, as well as a tree nursery. The utility gardens in Klemensów were a place of acclimation and reproduction of seeds and saplings imported to Poland. Thanks to the expanding possibilities of obtaining and exchanging them from foreign and domestic garden nurseries, over time, the garden in Klemensów became a unique collector's garden.

The research introduces rarely discussed problems in the field of conservation, including the adaptation of historic utility gardens. The results include the analyses of archival materials which have not been previously developed.
\end{abstract}

Keywords: Zamoyski Entail, landscaped park, collector's garden 


\section{Introduction}

The palace and park complex in Klemensów in its prime period was one of the most magnificent landscape gardens in the country. For over 200 years, it served as the country residence of the Zamoyski Entail, and during that time it was both a place where many wealthy magnates marvelled at its beauty and a prosperous economic body. If it were not for the lack of care and maintenance that led to the devastation of the park, as well as its location far from major urban centres, it could have aspired to be one of the most beautiful parks in Europe.

Over the decades, the park complex in Klemensów was subject to stylistic transformations introduced from Western Europe. The initial inspiration for the French gardens of Tomasz Antoni Zamoyski were expressed in the original form of the park. The 19th century marked revolutionary changes, both in the layout of the Klemensów gardens and in other works of garden art in Poland and elsewhere in Europe.

From the beginning of the 19th century the Ordynat Zamoyski's country residence included a fruit and vegetable garden known as the walled-off garden and greenhouses, and then from about 1842 it housed a plant and vine nursery as well as a centre for training gardeners. The utility gardens not only provided fruit and vegetables for the inhabitants of the palace, but it also became a place for the acclimatisation and reproduction of plant material transplanted in Poland from abroad. The new taxons of plants obtained in this way had an impact on the form of plant compositions used in the park complex.

Many publications have been written about the palace and park complex in Klemensów. More extensive research is possible, as a number of manuscripts have survived from the Zamoyski Entail Archive, which is currently held in the State Archive in Lublin and includes records from the eighteenth, nineteenth and the first half of the twentieth centuries, including invaluable correspondence between the gardener, M. Stępowski, and Stanisław Zamoyski, as well as manuscripts related to plant inventories from 1854 and 1858. However, these source materials have yet to be compiled and published.

So far the scope of research has focused on selected aspects, mainly devoted to the architecture of the palace in Klemensów. The initial research took place at the beginning of the 20th century (Wadowski, 1907; Tomkiewicz, 1920: 18-19). New and more extensive information about the palace and its creators were born from the research by Jerzy Kowalczyk (Kowalczyk, 1959: 211-233; 2003: 87-111), Euzebiusz Maj (1983) and Janusz Kubiak (1971: 73-81). This information was supplemented by publications on the interior of the palace and its furnishings (Aftanazy, 1995: 292-305; Zamoyski, 1989: 35-46; Ajewski, 1997; Rut, 2005). These works were based mainly on the archives and led to a number of subsequent publications by Danuta Kawatko, among others (Kawatko 1983).

The research on the park complex in Klemensów to date has concentrated mainly on the formal aspects of the transformation of the whole park as a work of garden art and on the search for its author (Kowalczyk, 2001: 175-192; Kubiak, 1971: 73-81). A slightly different study, which included a number of issues related to the conditions of the natural environment and their participation in the spatial shaping of the park, the characteristics of its existing state, the stages of shaping the garden and the maintenance and design guidelines, was undertaken in the study by Euzebiusz Maj (1983).

The issue of the utility gardens itself was omitted or treated marginally in publications on the park complexes. The first and foremost article describing the square garden, orchard, greenhouses and nursery was published in 1933 in Przeglad Ogrodniczy by Aleksander Korniejczuk. The author gave a fairly detailed account of the composition, arrangement and species selection in the usable part of the Klemensów garden in 1933, indicating its uniqueness (Korniejczuk, 1933: 355-365). Another publication describing these issues is the article by Joanna Dudek-Klimiuk (Dudek-Klimiuk, 2016: 66-68). 
In 2018, a detailed historical study of the utility gardens, as a separate functionalspatial fragment of the palace and park complex in Klemensów, was made on the basis of an archival and bibliographic search (Chęć 2018). The study led to the reconstruction of the species selection for the utility gardens for the years 1854-1858 and the 1930s and 1940s, as well as a reconstruction of the garden's planting layout. The above work formed the basis for the present publication and a broader exploration of its significance in the functioning of the entire garden system. In this context the present work, based on an analysis of archival materials that have not been researched so far, complements the body of information on the park layout.

The broader context of the issue of the utility gardens, as a type of composed object (i.e. orchards, vineyards, kitchen and herb gardens) became the subject of numerous deliberations and studies by A. Zachariasz, A. Chmielewska, J. Dolatowski, J. Dudek-Klimiuk, D. Sikora, A. Bieleń-Ratajczyk et al.

\section{Historical outline of the complex's foundation}

The first archival references regarding the establishment of the Klemensów garden appear at the beginning of the construction process of the Baroque-style palace between 1744 and 1746. The creator, or at least co-creator, of the complex may well have been the palace's steward, Tomasz Antoni Zamoyski,

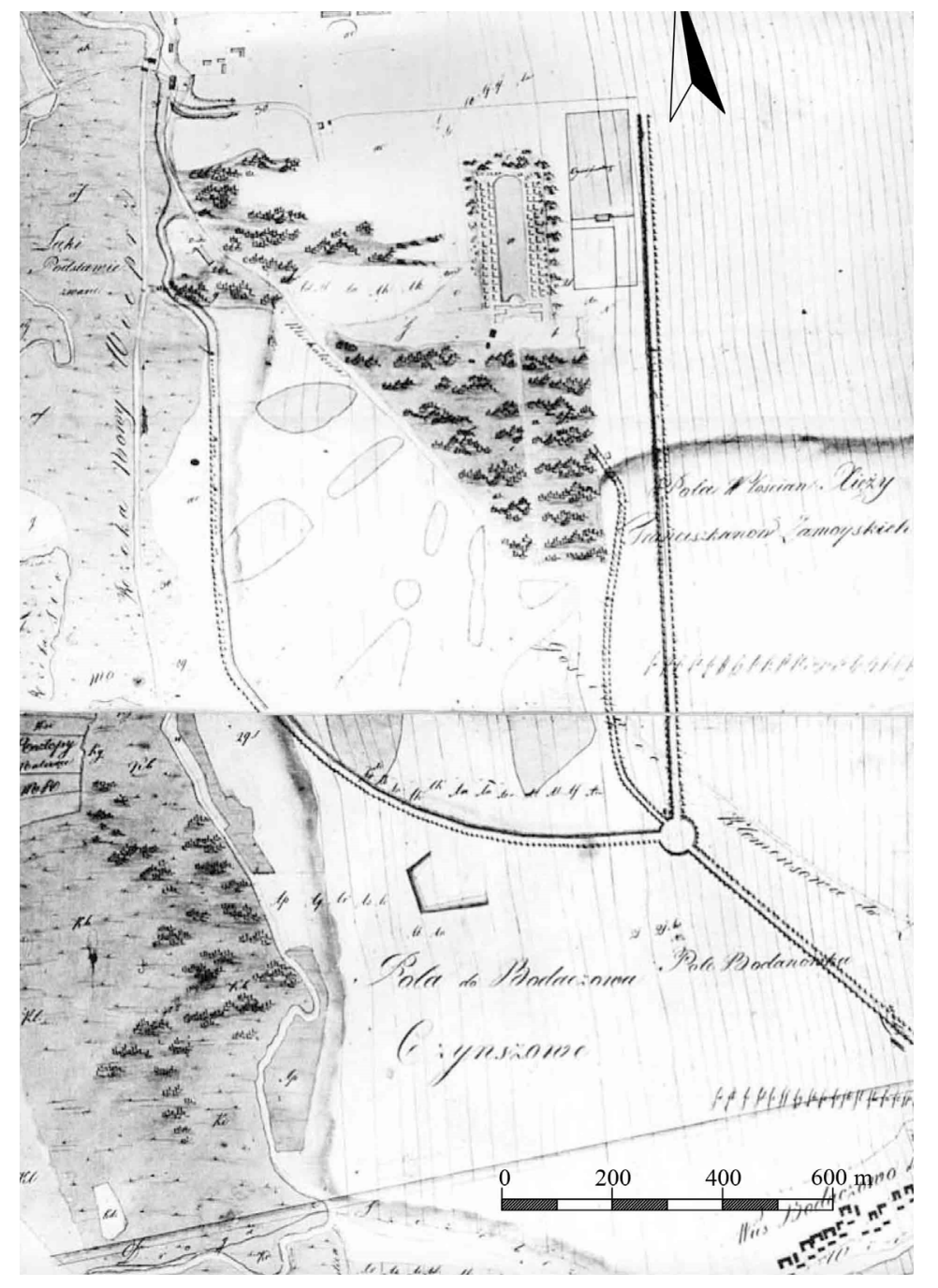

Fig. 1. Plan of the park from 1806 (J. Kubiak, Unknown plan of the Klemensów Park from 1806, KAiU 1971, z. 1, fig. 2) who was also the author of 'Atreatise on gardens', the first Polish treatise on gardening (Kowalczyk, 2001: 175-192).

The next set of archives concerning the park appeared at the beginning of the $19^{\text {th }}$ century. This was a copy of the Plan of the Klemensów Neighbourhood (Fig. 1), made in 1806 by a geometrician, Danielski, showing the state of the eighteenth-century garden (Kubiak, 1971: 73). The original spatial layout of the complex shows the impact of French art patterns, as admired by Tomasz Antoni Zamojski. The garden adjoined the palace from the northern side and its layout was symmetrical and uniaxial. Running along the palace's axis was an elongated parterre in the form of an indenter. The composition was surrounded by double rows of lime trees on both sides. These trees can still be seen today.

At the beginning of the $19^{\text {th }}$ century, Stanistaw Kostka Zamoyski and his wife Zofia née Czartoryski sent an order to expand the park (Fig. 2) during one of their many trips around England. Thus, from a small park measuring around 20 hectares, it grew into an extensive English-style complex with a total area of more than 130 hectares. The axial arrangement was not only abandoned but even erased during that period. It was replaced by free arrangements with carefully composed views and varied plant cover. One can say that this was indeed the period when the garden reached its full glory, as the members of the Zamoyski Entail have not been engaged in this project to such an extent since then. A utility garden separated by a tall brick wall was established in the eastern part of the area and a conservatory used to cultivate exotic trees, shrubs and perennials was added to the western wing of the palace.

All of these actions had an impact on the role played by the residence of the Zamoyski Entail, in 


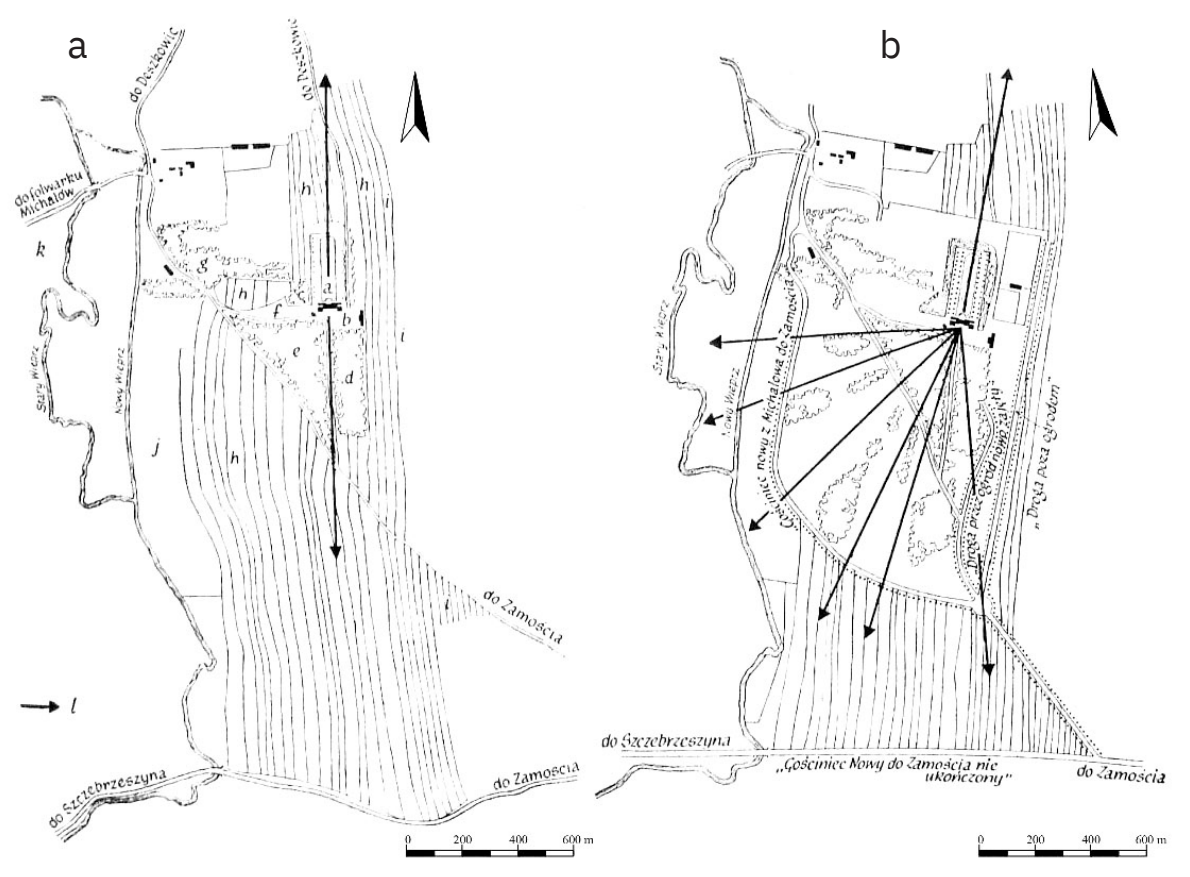

Fig. 2. Plans of the garden in Klemensów (ed. J. Kubiak, KAiU 1971, z. 1, fig. 3 and 4): a) Reconstruction of the 1806 state, prepared on the basis of a copy of the Plan of the Klemensów Neighbourhood. Explanation: $a$ - palace and garden, $b$ - palace courtyard with Murgrabi's buildings and lord's stables, $\mathrm{c}$ - birch forest, $\mathrm{d}$ - hay meadow, e - hay meadow, $f$ - wasteland, $g$ - wasteland, $h$ - land of the Bodaczowski farmers, i - land of the Franciszek Zamoyski landlords, j - land of the Michałów folwark, k - Michałów folwark, b) Project of the garden in Klemensów transferred onto the copy of the plan from 1806 contrast to its original purpose. Its representative significance, something typical for a nobleman's residence, i.e. a centre of power, diminished in favour of expanding the facility's economic functions, which are more characteristic for landed gentry residences.

Further development of the park was a continuation of the concept of Stanistaw Kostka and Zofia Zamoyski. In 1897 the western border of the park was moved to the newly formed, probably in the 18th century, bed of the Wieprz River. The garden area was enlarged by the riverside meadows. From the east, a narrow strip intended for Nurseries and the New Garden was incorporated into the park, eliminating the area previously used as a path. The new path to Michatów was designated to run parallel to the new garden boundary (Fig. 3).

According to Jan Zamoyski, son of Maurycy Klemens, at the beginning of the $20^{\text {th }}$ century the appearance of the former linden avenue in the French style was restored by removing groups of trees planted in the second half of the $19^{\text {th }}$ century.

After World War II the palace and park complex was significantly transformed, and the lack of proper use initiated a series of destructive activities related to the complex. The most noticeable manifestation and cause of the devastation was the change in the function and owner of the complex. The Land Reform of 1944, introduced in Poland, assumed the parcelling out of all estates and taking them away from their rightful owners (Boguszewska K. i Boguszewska M. 2015: 31). From the middle of 1945, the Klemensów estate was taken away from the Zamoyski family by a decree of the PKWN. The State Treasury became the owner of the palace, and the building itself remained under the care of the Congregation of the Franciscan Sisters, who ran an orphanage in the palace. During this period the walled-off garden and the New Garden continued to be used as they were intended. The modest decoration of the geometric garden parterres behind the palace and the flowerbed in the main courtyard were also maintained.

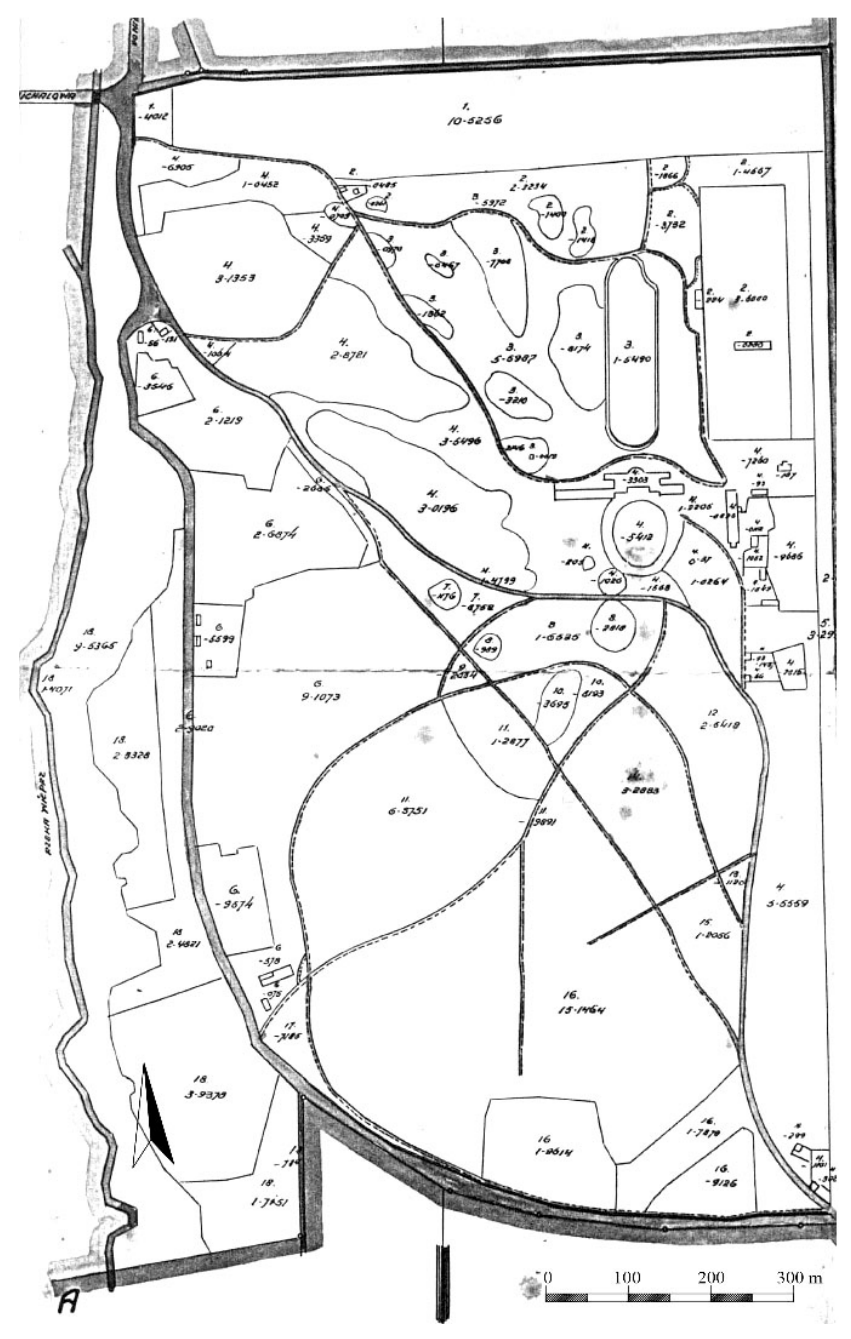

Fig. 3. Land plan of the park and palace in Klemensów, from 1935, APZ, Mortgage of the Zamość Entail 
Fig. 4. View of the front part of the palace, 1960-1965 (Source: Fotopolska)
In the 1950s, the use of the palace and park complex was divided between two new users - the State Adult Welfare Home and the State Agricultural Farm in Michatów. The end of the 1960s and beginning of the 1970 s saw an intensification of farming, which was incompatible with the original and contemporary role of the park as a leisure facility. The lack of permanent maintenance resulted in blurring of the layout and significant destruction of the landscape and forest

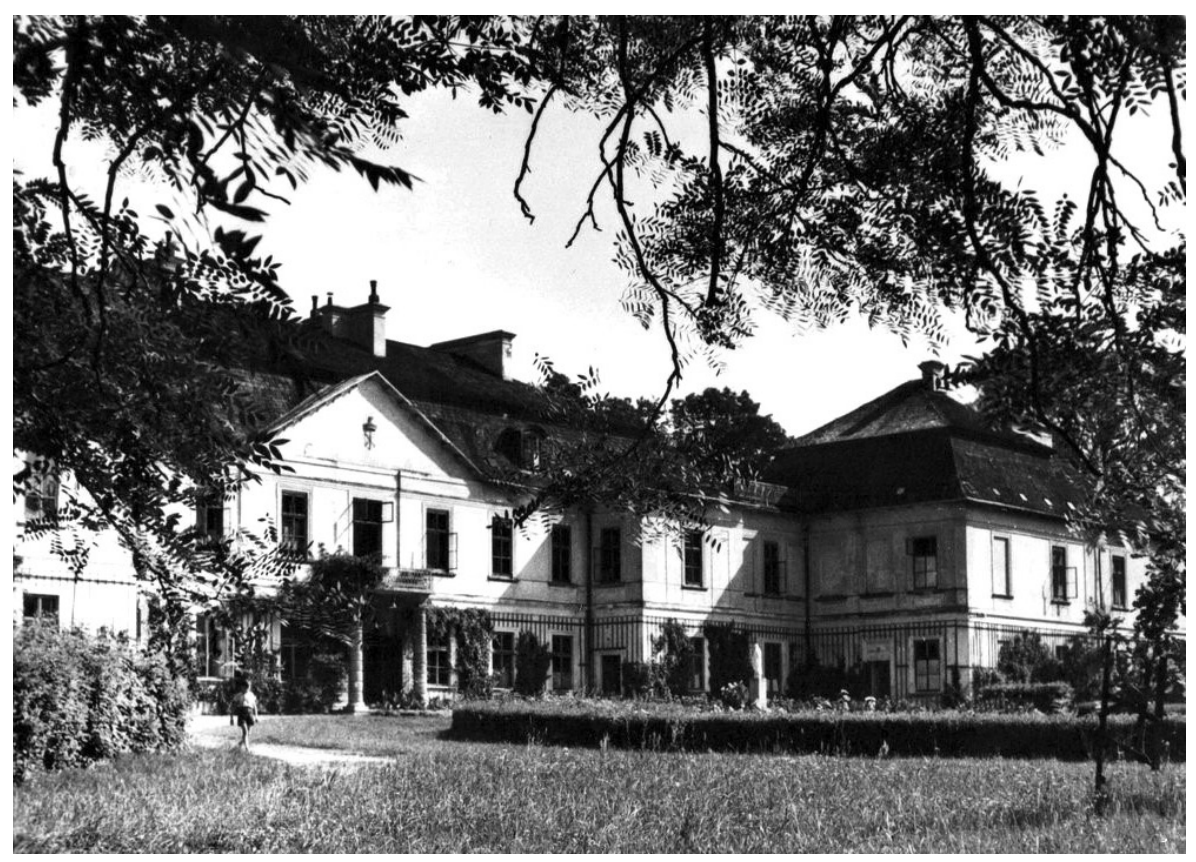

parts ${ }^{1}$. Neither the nursing works necessary for maintaining the park nor specialised restoration care were carried out (Fig. 4).

Due to the necessity for the State Treasury to bear the costs of current repairs to the palace as well as the whole monument, which needed immediate work to regain its former splendour and glory, the property was sold to the heirs in 2017.

The current compositional layout of the park differs from the originally composed layout in a landscape spirit. As a result of the long years of neglect of the park, the former view perspectives have been lost while the clearings have been concealed by self-seeding plants.

\section{Utility gardens}

Although the vegetable garden and orchard belong to the oldest part of the park, which was founded at the beginning of the $19^{\text {th }}$ century, the food production activities in Klemensów date back to as late as 1842 when a plant and vine nursery and gardener training centre were established. At first, The Zamoyski Entail Nurseries in Klemensów were managed by Sierugowski. Afterwards, they were taken over for several decades (until 1927) by Bernard Malthan, an outstanding gardener and pomologist from Brandenburg (Dolatowski, 1999: 38). The nursery activities mentioned in the archives continued until the outbreak of World War II.

The areas intended for growing crops were in the north-western part of the park complex. The composition of the utility garden was laid out in accordance with French design. The garden itself had the form of an elongated rectangle walled-off with a 2.5-metre-tall brick wall, whose sides measured 115 by 320 metres.

The archives of the Regional Conservator of Monuments in Lublin contain the opinion on the condition of the park from 24/10/1959, developed by a special commission led by Prof. Gerard Ciotek. 


\section{口:: technical E口transactions}

No. $2021 / 010$

The wall protected the plants from cold winds, thereby creating a microclimate that was warmer than the local one. The orchard was situated in the northern part of the, area and the vegetable garden, which was further separated into internal brick quarters, occupied the southern part (Fig. 5). A gardener's house with two adjacent utility buildings was built between these two zones (Fig. 6).

To the south and west of the walled-off garden was a large park, whereas to the north of it was the border of the arable lands of the Michalów Grange. The eastern side, on the other hand, was an area dedicated to nursery planting.

\subsection{Potażeryia vegetable garden, orchard and nursery in the $19^{\text {th }}$ century}

According to archive records from 1872, the walled-off utility garden covered an area of 3.36 hectares, and the nursery area - later referred to as the Old Garden - 0.56 hectares (State Archive in Lublin) (Fig. 7). In the following years, perhaps due to the expansion of nursery activities, the park area was expanded by adding the New Garden and New Orchard, which were intended for growing trees, shrubs and vegetables (Korniejczuk, 1933: 355-359).

During the mid-nineteenth century, most vegetables grown in the garden were planted in beds. The archives mention that fruit trees, fruit and ornamental
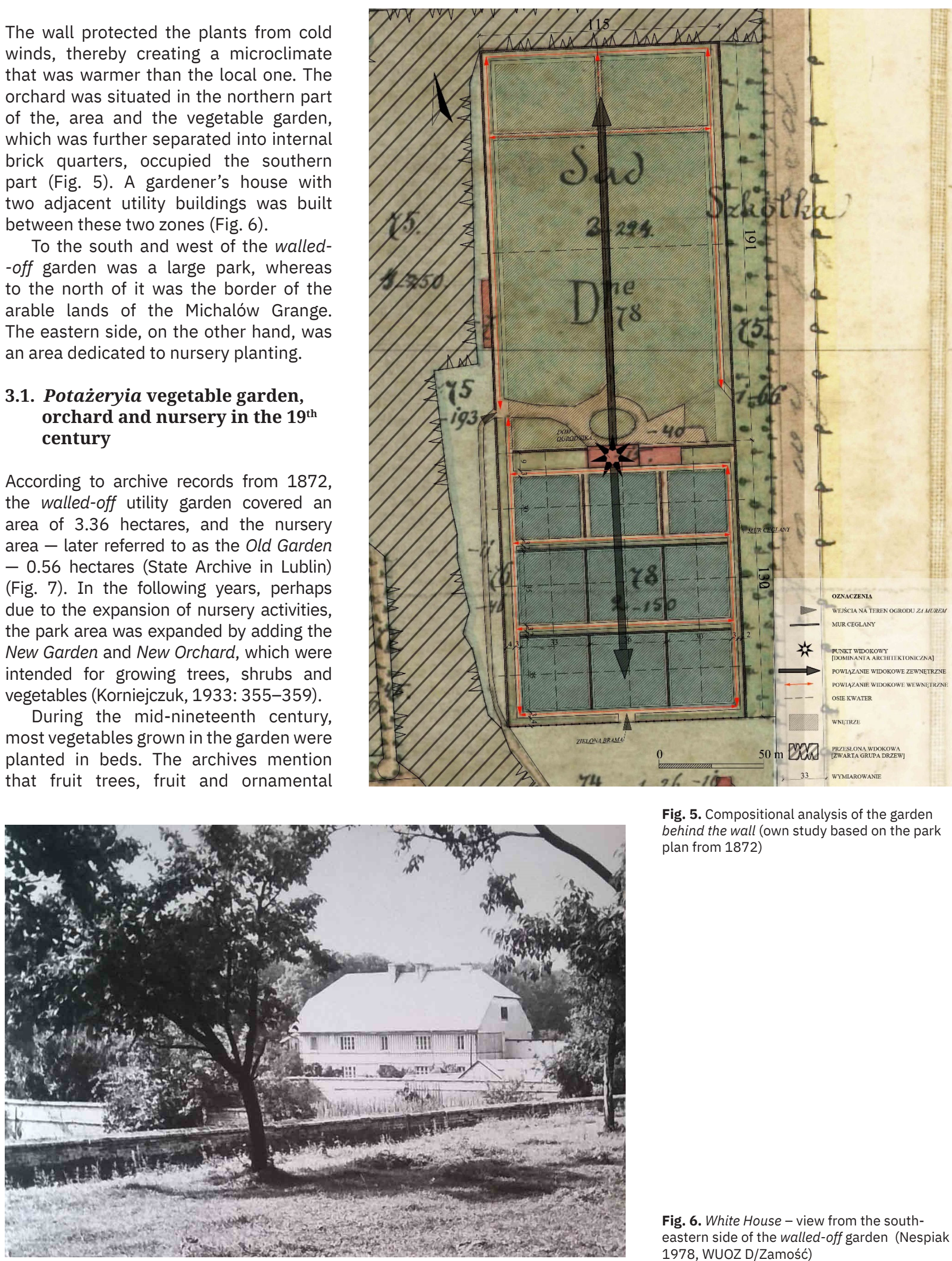

Fig. 5. Compositional analysis of the garden behind the wall (own study based on the park plan from 1872)

Fig. 6. White House - view from the southeastern side of the walled-off garden (Nespiak 1978, WUOZ D/Zamość) 


\section{a:: technical

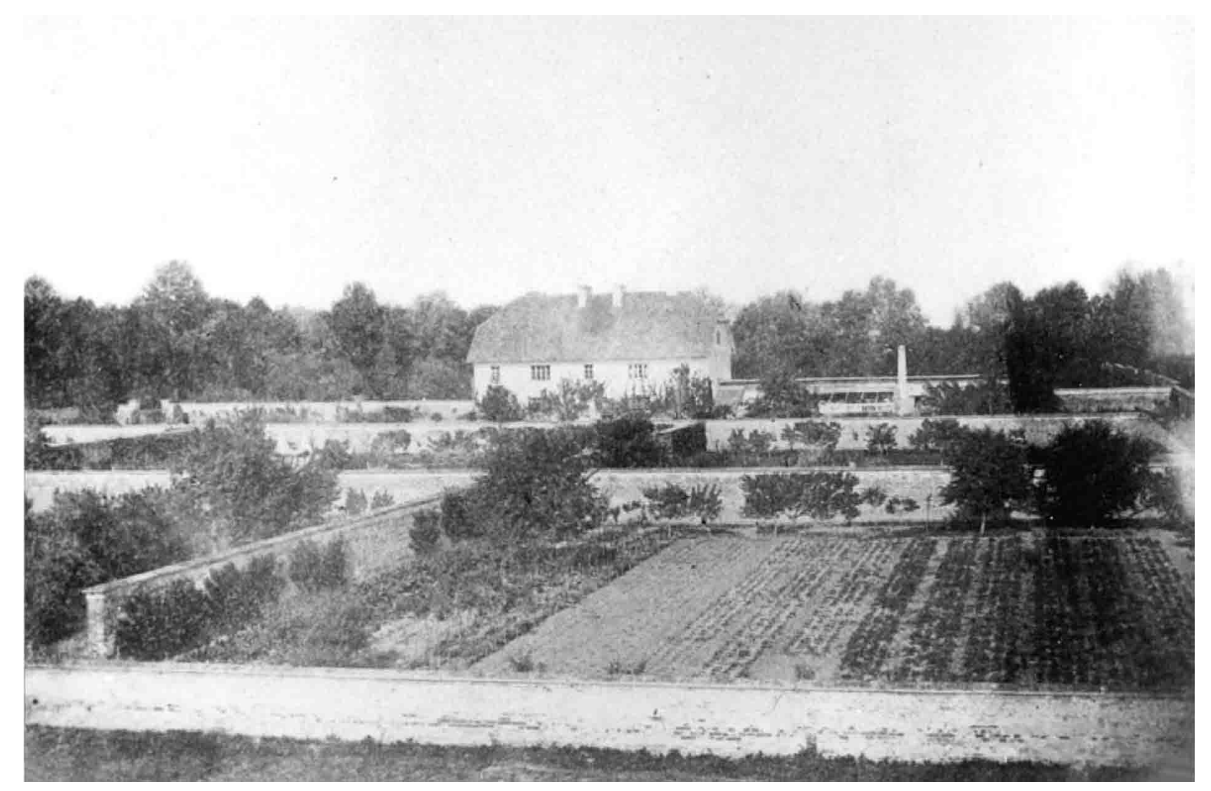

Fig. 7. View from the southern side on the square garden (Photograph taken after 1870, Collection of Andrzej Zamoyski) shrubs, perennials and fruit-bearing creepers were cultivated there as well. Flowerbeds with annual and perennial flowers further improved the aesthetics. Both native and exotic species, with the latter requiring special horticultural skills, were included in the taxa cultivated. Shielding such plants from blizzards incoming from the north and frosty winds from the east and west was particularly important. This was achieved by erecting a wall around the garden, which was further separated into 9internal quarters. This created a kind of a greenhouse and made it possible to grow plants sensitive to frost in the garden.

The species of fruit trees cultivated there included native cherry, pear and plum trees as well as stenothermic apricot and peach trees. As for shrubs, both wild and cultivated varieties of roses and lilacs could be found in the garden. Grapes were also cared for lovingly and they climbed up the southern walls of the gardener's house and the quarter garden. The large-scale bed cultivation of vegetables included root vegetables, leafy greens and other types.

At the southern side of the Ogrodniczówka, there were orchards containing dwarf and creeper trees. The orchard was maintained in good order and a large section of it was devoted to a fruit tree nursery. The plant species cultivated there included pear, apple, plum and cherry trees of various varieties, i.e. dwarf and wild specimens, as well as fruit-bearing, biennial and triennial trees. Gooseberry, currant and quince bushes were planted between the rows of trees.

A nursery located in the western part of the complex was vital for the utility part of the garden. It was used to grow and propagate trees, shrubs and decorative perennials, which were then either planted in the walking area or sold. The extensive plant collection mainly contained species of foreign origin. 90 species and varieties of trees and shrubs, primarily deciduous, were among more than 1000 specimens collected there. The collection was supplemented by 57 taxa of perennial flowers, which embellished flower beds housing trees and shrubs or were formed into bouquets to decorate the palace interiors. Nevertheless, it should be noted that the role of flower production at the Klemensów garden was of rather marginal importance at that time.

\subsection{Perennial garden, orchard and nursery in the $20^{\text {th }}$ century}

From the very beginning of the $20^{\text {th }}$ century, there was a significant increase in the range of plants offered by the nursery. The Klemensów garden's longstanding tradition of cultivating fruit trees was not at all abandoned, however. Nonetheless, it is evident that tree cultivation became largely limited to typical orchard species, which were cheaper and easier to maintain. Cultivation focused primarily on creeper and dwarf species of apple, pear, plum, cherry and sweet cherry trees. Apricots and peaches were also introduced. Another group of plants offered by the garden in many different varieties were perennials, whereas vegetable cultivation was limited to such an extent that it only covered the needs of the complex inhabitants themselves. Mother plants were imported from France, Spain, Germany, Russia and southern Mexico (Dolatowski, 1999: 38).

The quarter garden had gained anew function and was now to be used as a perennial garden, where more than 100 species of flowers in 250 varieties would be grown in the soil as well as portable frames. Vegetable cultivation, on the other 
hand, was minimised to just a few beds and portable frames (Figures 8 and 9). The perennials grown there included pot, ground and flowerbed varieties. Species such as phloxes, asters, irises, larkspurs, peonies, gladioli, dahlias and roses were held in especially high regard. Marvellous flowerbeds were used to grow flowers for sale, as well as for the purpose of decorating the palace's interior. In these quarters, since they are shielded from the wind, huge quantities of various species and varieties are cultivated, all planted in flowerbeds that almost never fade (Korniejczuk, 1933: 358). The composition was complemented by trees and shrubs, and in this case, the types of species cultivated had remained unchanged since the mid-nineteenth century.

Among the perennials, there were many Dutch, French, American and Asian cultivars. The cactus, pompon, peony, two-colour, collarette and American dahlias grown in the garden in more than 100 varieties were widely renowned.
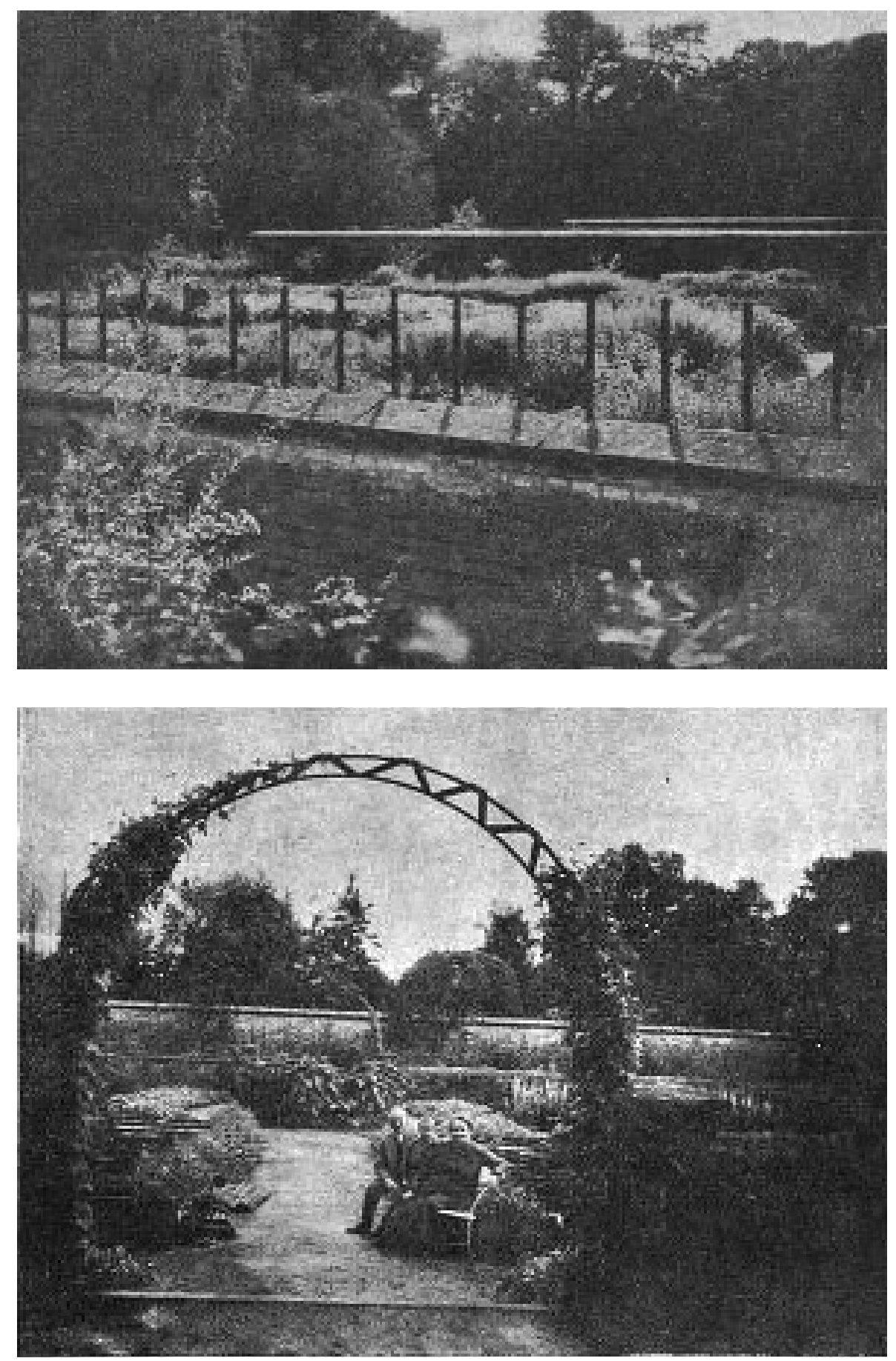

Fig. 8. View of the plots and the perennial garden, 1930s (Photo. P. Dąbrowski, Korniejczuk 1933, p. 356)

Fig. 9. Exit to the cold frame, 1930s (Photo. P. Dąbrowski, Korniejczuk 1933, p. 356) 
131 cultivars of noble rose varieties growing on the outside of the long wall were an equally impressive collection as well. The quarter garden was full of phloxes, cultivated there in over 40 varieties, as well as Dutch tulips, carnations and larkspurs.

Unlike the quarter garden, the Old Orchard was not transformed. Its function, composition and the type of species cultivated in it remained unchanged for more than 70 years. At that time, plant cultivation was still based primarily around fruit species, just as in the mid-nineteenth century. The new additions included walnuts, medlars and dogwoods.

During the pre-war period, a German man named Mathan was the garden's main caretaker. He worked there for several decades and had grown immensely popular in the area. He was a bit strange in his old age, but his fruits were wonderful, and he liked flowerstoo (Klukowski, 1958: 155). Following Mathan's death, between 1927 and 1931, the position of the gardener was held by Henryk Mazur, who was truly in love with flowers and had many beautiful specimens (APL). This function was then taken over by Tomasz Urbaniak who was assisted by qualified gardeners and other manual labourers.

After World War II, both the Zamoyski Entail and the nursery were subject to land reform and were taken over by the Polish state. At that time the palace served as a social welfare home. The composition of the park underwent a process of naturalisation. The functions of the utility gardens were considerably reduced and were maintained by the Franciscan Sisters in a symbolic way, deviating from the original assumptions. The original species base became poorer and the architectural elements, which were not maintained or repaired, underwent progressive degradation.

The garden's composition is still visible today, but the utility functions of the Klemensów complex were all but abandoned. The plant cover clearly differs from the vegetation which was originally grown there, and cultivating vegetables, flowers and perennials have been completely forsaken. Only the post-war fruit trees and remains of the architectural features of the garden i.e. a brick wall surrounding the former orchard and vegetable garden and the internal wall dividing the quarters, have survived until today.

\section{Adaptation possibilities}

Nowadays, the traditional production functions of the utility gardens situated by the restored park complex - both in regard to edible and ornamental plants - are simply impossible to maintain due to the low economic value of such crops. Regardless, owing to reasonable adaptation, many such facilities have retained their original spatial arrangement and occasionally even the species selection. Additionally, the specificity of the Klemensów gardens is not only their "usability" understood as described above, but also their nursery purpose.

The Orchid Garden in tańcut, located near Klemensów itself, is a good example of this. There, a complex of utility greenhouses which cultivated plants for the palace palm house at the turn of the $20^{\text {th }}$ century was replaced with an interesting exhibition and gastronomic facility. A significant portion of it is still intended for cultivating and adapting a collection of Orchidaceae family plants and remains close to its original purpose, however. Czerniakowski provides adescription of the history of this place, its transformations and the characteristics of the collection itself (Czerniakowski, Pańczyk and Olbrycht, 2012: 77-81). Maintaining the nature of utility gardens was also achieved in the park-arboretum in Gotuchów. Here the manager of the area (Forest Culture Centre) has maintained the function of a collector's garden on the site of the former nursery. The pineapple house and historic vineyards have been restored, and a section has been adapted as a flower and herb garden. The old stock of trees and bushes, from which material for further plant reproduction can be obtained, also appears to be unique in this context. Due to the educational programme run by the State 
Forests, the education of visitors has become the leading function in the further activities of the adapted facility. The Gotuchów park has managed to retain its original character as well. The Forest Culture Centre in Gotuchów, run by the State Forests, operates on the premises of a former nursery, established to fulfil the needs of the landscape park, and houses a collection of ornamental plants. In this case, the primary function of the facility is education. In the case of the utility gardens at the Bolestraszyce Arboretum, which was founded on the grounds of the former palace park, a similar transformation has occurred. A utility garden surrounded by a wall was recreated for educational purposes and it now allows the Arboretum to maintain small-scale production and adaptation of plants for its own needs. The plant collection is further complemented by apple trees situated by the wall, as well as biblical and creeper plants. When it comes to historical rather than botanical education, one may also mention such examples as the kitchen gardens in Nieborów or the Queen Bona gardens at the Wawel Castle, which are both examples of successful restorations of old garden compositions. Nonetheless, such a development direction is a reasonable choice only in the case of museum-type facilities such as the ones mentioned above, and can hardly be called an 'adaptation' in the strict sense of the word.

Another adaptation direction for former utility gardens is providing the gastronomic and hotel facilities established in former manors and palaces with healthy foods and spices. Examples include the Anna Manor in Jakubowice Konińskie and the palace and park complex in Bystrzejowice near Lublin. The managers of these businesses pride themselves on serving food made using produce grown in their own gardens. Regardless, due to the need to maintain economic balance and the relatively low output of the local production in respect to the demand, such claims become merely a marketing trick in a very short time.

An interesting background for Polish adaptations involves the achievements in other countries. An inspiring example of such a transformation, primarily due to its permanence, is the walled-off kitchen garden near the Highgrove estate belonging to Charles, Prince of Wales, which was described by Chmielewska (Chmielewska, 2012, 91-100). The cultivation of edible plants with the additional organic production aspect is a proven solution that has worked well for several decades. It seems that reducing output expectations and moving away from commercial production may be a much more suitable adaptation direction for royal court or palace and park facilities.

The gardens of Arundel Castle (in West Sussex, on the south coast of England) can be described as an example of an exceptional adaptation of a 20-hectare park. The contemporary redevelopment measures are focused on aesthetic, utilitarian and educational values. The utility gardens, strongly linked to the tradition of the site, were divided into plots, separated by hedges. Each of them was assigned a separate function. The kitchen garden, where vegetables used in the castle restaurant are grown, the bouquet garden, where material for decorating the rooms is obtained, and the orchard with the oldest varieties of English apple, pear and plum trees. The garden also has its own greenhouses. Individual sections of the garden also have a collection function. The gardens in Arundel are a good example of a unique setting for a listed building, combining natural and cultural aspects. At the same time, the care and maintenance of the complex itself does not require huge financial outlays and can be carried out by people without specialist training, under professional supervision (Marcinek, 2018: 74-81).

So, what are the adaptation possibilities and the chances of actually restoring the utility gardens in Klemensów? The conclusion that can be drawn not only from the theory of conservation of historic buildings, but also from the cited examples, shows a clear dependence between the new function given to the main object and the accepted directions of adaptation of the utility gardens. In the case of Klemensów, the future function of the palace is still unknown. The extent of the utility gardens is a factor that translates directly into the amount of the financial outlays necessary for their renovation, and then 
Fig. 10. The remains of the wall of the plot garden, 2017. View towards the south (Own study)

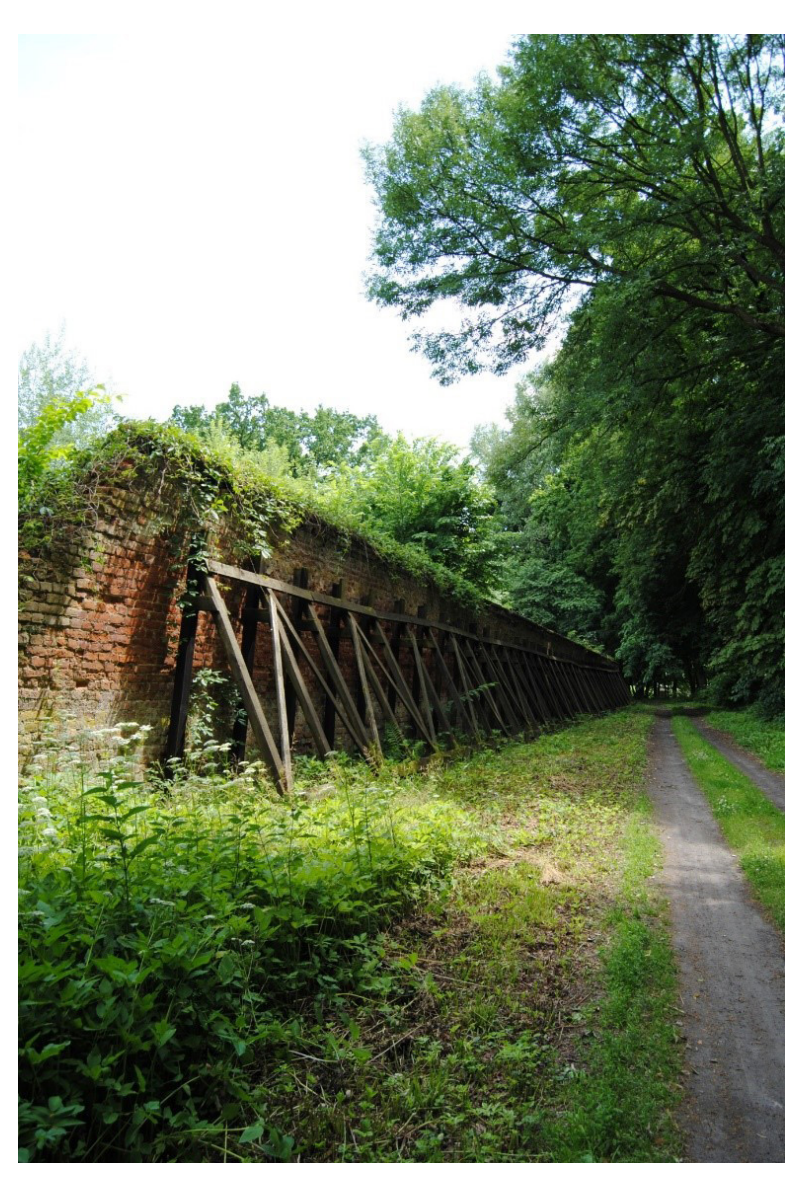

constitutes a significant obstacle in maintaining functions similar to the original ones. In addition, the portable frames are surrounded by a tall brick wall (Fig. 10) which would also be very costly to renovate. Regardless, the large surface area and compositional separation of the gardens make it possible to choose an autonomous method of adapting them to their new role, effectively making them functionally and spatially independent of the palace. This approach would render it possible for the complex to serve many functions at once, including educational, collector's, production and therapeutic ones. It is vital that any new composition (in terms of the utility garden's new role) maintains characteristic division into separate quarters and remains true to the historical tradition when it comes to the plants cultivated at Klemensów.

In outlining the priorities for the proposed restoration measures, it is proposed to carry out the restoration of the walls first and then reconstruct the geometry of the plot garden. The best way to achieve this would be to recreate the communication system in the form of paths made of natural aggregates. As an alternative solution, strips of regularly mown turf could play this role. Parallel to these activities, the original collection should be gradually restored. It could be located in a few selected plots and, within the means to maintain them, extended to other plots. Such activities would make it possible, at relatively small cost, to focus on the two most important values of this part of the park, i.e. preservation of the spatial arrangement of the utility gardens and nurturing of the plant collection.

\section{Summary}

As opposed to the park, the regular layout of the walled-off garden has remained unchanged for over two centuries. Nonetheless, the quarter distribution and the species composition had been transforming over the years as a result of the expanding knowledge of botany and gardening and the changing needs of the palace owners.

The utility gardens were an inseparable piece of the economic body that was the Klemensów palace and park complex, and as such, they performed many functions. Apart from selling plant material to local buyers and obtaining seeds and seedlings of fruit and decorative plants, the Klemensów gardens were also a place in which plants that were to be grown in Poland could be adjusted to the local conditions and reproduced. The plants obtained in this way were then used to create the park. Few places in Poland contained a comparable collection of plant species and varieties. It should be emphasised that labels in Polish and Latin containing information on the plant's species, variety, origin and even the date of planting or sowing, which could be found at Klemensów, were something of a rarity among other palace and park complexes (Korniejczuk, 1933: 355-365). 
Thanks to the expanding possibilities of obtaining and exchanging seeds and saplings from foreign and domestic gardening nurseries, the Klemensów garden was, in fact, a true collector's garden.

The whole park, as an example of garden composition, should undergo a comprehensive revalorisation. First of all, the state of preservation of the park should be documented through an inventory. Then by skilfully using the natural values of the habitat and the shape of the terrain, the former view perspectives should be recreated and the original planting groups completed with such species as: larches, Weymouth pines, poplars, birches, spruces and lime trees. Such basic and necessary actions would allow the preservation of the compositional values of this unique object.

As a background to these activities, a special role could be played in the restoration of the utility gardens and of their historical function by the preparation of plant material for the permanent and successive replacement of plants within the park complex. The acquisition of nursery material from the existing tree and shrub stands, as well as acclimatisation of plant material from foreign and domestic nurseries, could serve to propagate and produce in situ plants best suited to the historical and habitat conditions of the Klemensów garden. The plants obtained in this way would constitute the material used in the park's revalorisation, while the utility gardens would provide a base for the collection of nursery material for the restoration and current additions to the plant cover in the park.

\section{References}

Aftanazy, R. (1995). Klemensów, Dzieje rezydencji na dawnych kresach Rzeczpospolitej. Województwo betskie, Ziemia Chetmska, województwa ruskie. Wrocław-Warszawa-Kraków: Zakład Narodowy im. Ossolińskich. (6): 292-305.

Ajewski, K. (1997). Zbiory artystyczne i galeria muzealna Ordynacji Zamojskiej w Warszawie, Koztówka. State Archive in Lublin, Archive of the Zamość Entail of Zwierzyniec.

Boguszewska, K., Boguszewska, M. (2015). Problematyka wspótczesnych zagrożeń wybranych zespołów pałacowo-parkowych ordynacji Zamoyskiej. Czasopismo Techniczne. Architektura. 5-A: 15-31.

Chęć, E. (2018). Studium historyczne ogrodów użytkowych w obrębie zatożenia patacowo-parkowego w Klemensowie. Warszawa: Master's thesis written at the Department of Landscape Architecture at the Warsaw University of Life Sciences under the supervision of Ph.D. J. Dudek-Klimiuk.

Chmielewska, A. (2012). Miejsce i funkcja ogrodów użytkowych w różnych założeniach ogrodowych na przykładach: parku rezydencji książąt Radziwitłów Nieborowie, ogrodu Księcia Walii Karola oraz ogrodu plebańskiego parafii rzymskokatolickie w Żelechowie. Czasopismo techniczne. Architektura. 8-A: 91-100.

Czerniakowski Z., Pańczyk D., Olbrycht, T. (2012). Storczykarnia zamku w Łańcucie, Czasopismo techniczne. Architektura. 8-A: 77-81.

Dolatowski, J. (1999). Szkótkarstwo polskie 1799-1999, Warszawa: Polish Nurserymen Association, Greenery Promotion Agency.

Dudek-Klimiuk, J. (2016). Ogród w Klemensowie, Materiaty VII zjazdu PTD. Drzewa, parki i ogrody. Dziedzictwo kultury i natury Matopolski Wschodniej. Polskie Towarzystwo Dendrologiczne, Bolestraszyce i Lwow, 23-25 September 2016, 66-68.

Fotopolska (online). Retreviered from: https://wroclaw.fotopolska.eu/foto/346/ 346678.jpg (access: 24/04/2018).

Kawałko, D. (1986). Klemensów. Zespót patacowo-parkowy. Zamość: Office for Research and Documentation of Monuments.

Klukowski, Z. (1958). Dziennik z lat okupacji Zamojszczyzny (1939-1944), Lublin: KUL University Library, Rkps. 812, 155. 
Korniejczuk, A. (1933). Klemensów. Przegląd Ogrodniczy, 11-12: 355-365.

Kowalczyk, J. (1959). Architekci Zamoyskich w XVIII wieku, Kwartalnik Architektury i Urbanistyki, 1/2-3/4: 212-234.

Kowalczyk, J. (2001). Traktat o ogrodach Tomasza Antoniego Zamoyskiego z okoto 1750 roku. Biuletyn Historii Sztuki, 1-4: 175-192.

Kowalczyk, J. (2003). Zainteresowania i działalność architektoniczna ordynatów zamojskich w XVIII wieku, Ziemiaństwo na Lubelszczyźnie. Materiaty II sesji naukowej zorganizowanej w Muzeum Zamoyskich w Koztówce 22-24 maja 2002., Ed. Maliszewska R. Koztówka, 87-111.

Kubiak, J. (1971). Nieznany plan parku klemensowskiego z 1806 roku. Kwartalnik Architektury i Urbanistyki, 1: 73-81.

Tomkowicz, S. (1920). Ordynaci zamojscy i sztuka XVI-XIX wieku, Teka Zamojska, vol. 4.

Maj, E. (2003). Mecenat artystyczny ordynatów Zamoyskich w sztuce ogrodowej na przykładzie Zwierzyńca i Klemensowa, Ziemiaństwo na Lubelszczyźnie. Materiaty II sesji naukowej zorganizowanej w Muzeum Zamoyskich w Koztówce 22-24 maja 2002, Ed. Maliszewska R. Koztówka, 169-181.

Marcinek, R. (2018), Ogrody zamku Arundel. Tradycyjna atrakcja w zaskakującej odstonie, Wiadomości Konserwatorskie, 54: 74-82.

Rut, M. (2005). Pałac w Klemensowie. Wiejska rezydencja ordynatów zamojskich. Lublin: Doctoral thesis written at the Department of Modern Art History of the Catholic University of Lublin under the supervision of prof. Jerzy Lileyko.

Zachariasz, A. (2012). Piękno i użyteczność - o sztuce uprawy roślin użytkowych, Czasopismo techniczne. Architektura, 8-A: 27-39.

Zamoyski, J. (1989). Zbiory Zamoyskich w Klemensowie, Z dziejów kolekcjonerstwa na Lubelszczyźnie, Lublin, 35-46.

Wadowski, J. A. (1907). Kościoty lubelskie, Kraków. 